The New Chimpanzee 



\title{
The New Chimpanzee
}

\author{
A Twenty-First-Century Portrait \\ of Our Closest Kin
}


Copyright (C) 2018 by the President and Fellows of Harvard College All rights reserved

Printed in the United States of America

First printing

\section{Library of Congress Cataloging-in-Publication Data}

Names: Stanford, Craig B. (Craig Britton), 1956- author.

Title: The new chimpanzee : a twenty-first-century portrait of our closest kin / Craig Stanford.

Description: Cambridge, Massachusetts : Harvard University Press, 2018. I Includes bibliographical references and index.

Identifiers: LCCN 2017040032 | ISBN 9780674977112 (hardcover : alk. paper)

Subjects: LCSH: Chimpanzees-Behavior. I Primatology.

Classification: LCC QL737.P94 S727 2018 | DDC 599.885-dc23

LC record available at https://lccn.loc.gov/2017040032

Jacket design: Marcus Ferolito

Jacket photo: Minden Pictures 
Dedicated to the generations of chimpanzee researchers from Jane Goodall to the present day 
